\title{
Kleptoparasitism, disturbance and predation of yellow-legged gulls on Audouin's gulls in three colonies of the western Mediterranean*
}

\author{
ALEJANDRO MARTÍNEZ-ABRAÍN ${ }^{1,2}$, JACOB GONZÁLEZ-SOLIS ${ }^{3}$, \\ VITTORIO PEDROCCHI ${ }^{3}$, MERITXELL GENOVART ${ }^{1,3}$, JOAN CARLES ABELLA ${ }^{3}$, \\ XAVIER RUIZ ${ }^{3}$, JUAN JIMÉNEZ ${ }^{2}$ and DANIEL ORO ${ }^{1,3}$ \\ ${ }^{1}$ Institut Mediterràni d'Estudis Avançats IMEDEA (CSIC-UIB), Miquel Marquès 21, 07190 Esporles, Mallorca, Spain. \\ E-mail: a.abrain@terra.es \\ ${ }^{2}$ CPEMN Conselleria de Medi Ambient, Generalitat Valenciana, Avda. de los Pinares 106, \\ 46012 El Saler, Valencia, Spain. \\ ${ }^{3}$ Dept. Biología Animal, Vetebrats, Universitat de Barcelona, Diagonal 625, 08028 Barcelona, Spain.
}

\begin{abstract}
SUMMARY: The impact of yellow-legged gulls on Audouin's gulls was studied by means of observations from a blind, at the Ebro Delta, the Chafarinas Islands and the Columbretes Islands colonies, during different stages of Audouin's Gulls breeding cycle. The rates of predation (upon eggs and chicks) and kleptoparasitism (aerial and on courtship and chick-feeding regurgitates) were recorded to evaluate this impact. Kleptoparasitism and predation rates recorded at the three colonies may be considered low when compared with similar studies dealing with other gull species. It seems that interactions did not represent a threat to the population dynamics of Audouin's Gulls in any of the three colonies. The highest rates of aerial kleptoparasitism, courtship feeding and chick mortality were recorded at the Columbretes Islands, and the lowest at the Ebro Delta. The ratio of the number of yellow-legged gulls to the number of Audouin's gulls seems to influence the rate of disturbances. Food availability was also likely to play an important role in the number of interactions, which increased when food was in shorter supply. The study at the Ebro Delta and Chafarinas Islands was restricted to some subcolonies and hence results may not be necessarily representative of the entire colonies. The existence of some yellow-legged gull individuals specialised as predators was recorded. Finally, we discuss the suitability of several conservation measures commonly applied in colonies where both species breed syntopically.
\end{abstract}

Key words: kleptoparasitism, predation, disturbance, gulls, Columbretes, Chafarinas, Ebro Delta, conservation, seabirds.

RESUMEN: CLEPTOPARASITISMO, MOLESTIAS Y DEPREDACIÓN POR PARTE DE LA GAVIOTA PATIAMARILLA SOBRE LA GAVIOTA DE AUdOUIN EN TRES COLONIAS DEL MEDITERRÁNEO OCCIDENTAL. - El impacto de la gaviota patiamarilla sobre la gaviota de Audouin se estudió desde un observatorio en las colonias del Delta del Ebro Delta, islas Chafarinas e islas Columbretes, durante diferentes fases del ciclo reproductor de la gaviota de Audouin. Las tasas de depredación (sobre huevos y pollos) y el cleptoparasitismo (aéreo y sobre cebas nupciales y cebas a pollos) fueron registrados para evaluar este impacto. Las tasas de cleptoparasitismo y depredación registradas en las tres colonias pueden considerarse bajas en comparación con estudios similares llevados a cabo con otras especies de gaviotas. Las interacciones no parecen representar una amenaza para la dinámica poblacional de la gaviota de Audouin en ninguna de las tres colonias. Las tasas más altas de cleptoparasitismo sobre cebas nupciales, cleptoparasitismo aéreo y mortalidad de pollos se registraron en las islas Columbretes y las más bajas en el Delta del Ebro. La relación entre el número de gaviotas patiamarillas y el de gaviotas de Audouin pareció influir las tasas de molestias. La disponibilidad de alimento es probable que juegue también un papel importante en el número de interacciones, que aumentaron cuando el alimento fue más escaso. El estudio en el Delta del Ebro y las islas Chafarinas se restringió a unas subcolonias y por tanto los resultados no tienen que ser forzosamente representativos de la totalidad de la colonia. Se registró la existencia de determinados individuos de gaviota patiamarilla especializados en la predación y el clepto-

*Received July 9, 2001. Accepted December 9, 2002. 
parasitismo. Finalmente, se discute la conveniencia de diversas medidas de conservación aplicadas habitualmente en las colonias donde ambas especies se reproducen de manera sintópica.

Palabras clave: gaviota de Audouin, conservación, cleptoparasitismo, depredación, ave marina, gaviota patiamarilla, islas Columbretes, islas Chafarinas, Delta del Ebro.

\section{INTRODUCTION}

Interference competition occurs when one individual actively interferes with another individual's access to a resource. These interactions may be intraspecific or interspecific, can affect individual fitness and are common among birds, especially during the breeding season (Ricklefs and Miller, 2000). In gulls (Aves, Laridae), kleptoparasitism (i.e. aggressive stealing of food) is more or less opportunistic depending on the species (Brockmann and Barnard, 1979; see review in Furness 1987). Dominant species of gulls normally attack their hosts on arrival from the foraging areas (Hatch, 1975; Fuchs, 1977; Shealer and Burger, 1992; Oro and Martinez-Vilalta, 1994) and they can also predate on eggs and chicks (Bradley, 1986; Velarde, 1992). In turn, the subordinate species have developed defensive-avoidance responses of different intensity against their would-be kleptoparasites and predators (Burger and Gochfeld, 1988; 1992; Shealer and Burger, 1992; Cavanagh and Griffin, 1993; Le Corre and Jouventin, 1997). These behaviours include alarm calls or mobbing against the intruder, both at the individual and local population levels. When the subordinate species is vulnerable or threatened, interactions have a conservation concern since they can affect its population dynamics. Here we report on disturbance, kleptoparasitism and predation rates of yellow-legged gulls (Larus cachinnans) on Audouin's gulls (L. audouinii) at three colonies in the western Mediterranean, where the two species breed syntopically, in order to evaluate the potential effect of these interactions on Audouin's gulls. Since yellow-legged gulls are considered a threat for Audouin's gulls, several conservation measures such as culling have been adopted to protect Audouin's gull, which is a vulnerable and rare species. We finally discuss the suitability of these conservation measures commonly applied in colonies where both species breed syntopically

\section{MATERIAL AND METHODS}

The study was carried out in 1994 (April-June) at the colonies of the Ebro Delta $\left(40^{\circ} 37^{\prime} \mathrm{N}, 0^{\circ} 21^{\prime} \mathrm{E}\right)$ and the Chafarinas Islands $\left(35^{\circ} 11^{\prime} \mathrm{N}, 3^{\circ} 46^{\prime} 35^{\prime \prime} \mathrm{E}\right)$ and in 1997 at the Columbretes Islands colony $\left(39^{\circ} 54^{\prime} \mathrm{N}, 0^{\circ} 41^{\prime} \mathrm{E}\right)$, all of them located in the western Mediterranean. At the Ebro Delta, ca. 10,100 pairs of Audouin's Gull and ca. 1,600 pairs of yellowlegged gulls bred, while at Chafarinas the numbers were ca. 4,000 and 1,500 pairs respectively, and ca. 500 and 650 pairs on Columbretes (authors, own data). Audouin's gull's breeding schedule is delayed by about a month in comparison with that of the yellow-legged gull and the first hatching of the former occurs when yellow-legged gull chicks are about four weeks old. Yellow-legged gulls are larger than Audouin's gulls, with an adult body mass of 900$1,200 \mathrm{~g}$ versus $500-600 \mathrm{~g}$ respectively. Observations (342 hours at the Ebro Delta, $140 \mathrm{~h}$ at Chafarinas Islands and $63 \mathrm{~h}$ at Columbretes Islands) were carried out from a blind on 20-50 pairs of Audouin's gulls in each studied colony. Effort was distributed equally over the breeding stages of Audouin's gulls and over the days of observation to account for seasonal and daily variability in interactions between the two species.

Three types of interspecific kleptoparasitism were distinguished: (a) aerial pursuit, (b) food stealing during courtship feeding and (c) food stealing when parents fed the chicks. Two responses of Audouin's gulls to disturbance were also distinguished: (a) alarm calls and (b) agonistic responses after aerial or terrestrial intrusions. Predation was recorded as affecting (a) chicks or (b) eggs. The outcome of the interactions was always recorded except for aerial pursuits, since some of them ended beyond the field of scope from the hide. The success rate was defined as the number of events in which yellow-legged gulls obtained food against the number of events in which the outcome of the interaction was recorded. Since successful predation and kleptoparasitism events for yellow-legged gulls were few in comparison with the number of attempts (see Results), we defined rates as the number of attempts per observation unit effort. For the same reason, results from the three colonies were pooled to have an estimate of success rate for each interaction type. Aerial kleptoparasitism rates were calculated on the basis of the number of hours of observation correct- 
TABLE 1. - Rates of kleptoparasitism and predation attempts (both successful and failed, see Methods) at the three study colonies. Ni = total number of observations. Units: Aerial kleptoparasitism rate in number of interactions per hour, $\mathrm{N}=$ observation effort in hours of diurnal observation; courtship and chick-feeding kleptoparasitism in percentage of regurgitates stolen, $\mathrm{N}=$ total number of regurgitates observed; egg predation rate in number of attempts per 100 nests per day, $\mathrm{N}=$ hours*nests; chick predation rate in number of attempts per day and 100 chicks, $\mathrm{N}=$ hours $*$ chicks.

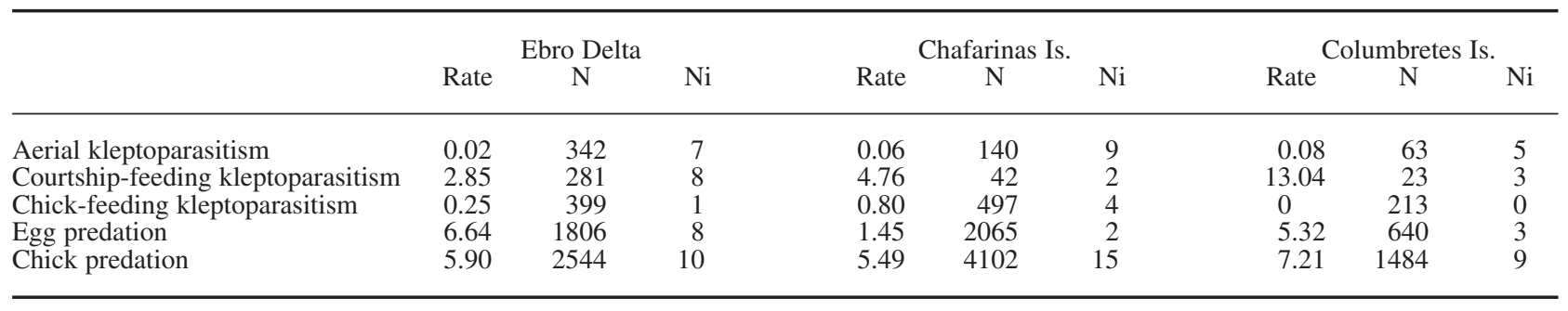

ed by the numbers of pairs observed; courtship and chick-feeding kleptoparasitism rates on percentage of regurgitates stolen against total number of regurgitates observed; egg predation rate on number of attempts observed per 100 nests per day; and chick predation rate on number of attempts observed per day and 100 chicks (to take into account the decrease in the numbers of chicks alive observed during the chick rearing stage).

When the size of the sub-colonies observed was sufficiently large (at Chafarinas and Ebro Delta colonies, but not at Columbretes colony), the results of breeding at the edge or at the centre of the subcolony were assessed. Only peripheral nests were considered to be at the edge, while the rest were considered to be at the centre. Three types of response were considered: first alarm call, defined as calls of alarm when a yellow-legged gull flew over the subcolony at low altitude and low speed; in some of these cases an agonistic response (taking off and chasing the intruder) by Audouin's gulls was observed and recorded as the second type of response; and third an agonistic response of Audouin's gulls to terrestrial disturbances, when yellow-legged gulls landed close to the study subcolonies. We did not record any case of landing in the centre of the sub-colonies so all the terrestrials disturbances started from the periphery of the subcolony. Owing to the low number of events recorded for the two areas (edge and centre) we pooled the observation from the two colonies, and we did not take into account the breeding stage or the age of the intruders (i.e. adults versus immatures of yellowlegged gull). These three types of response were also used to assess the differences in response rates (i.e. number of responses from total number of intrusions) of Audouin's gulls to disturbance by yellowlegged gulls among the colonies. For this comparison, data from the edge and the centre of the sub- colonies from the Ebro and Chafarinas colonies were pooled. To compare rates of interactions between the two species and types of response of Audouin's gulls depending on the colony, we applied non-parametric analysis of variance by ranks (Kruskal-Wallis test). To test for the edge effect, non-parametric rank tests were used (MannWhitney U tests).

\section{RESULTS}

Table 1 shows kleptoparasitism and predation rates at the three colonies. Aerial and courtshipfeeding kleptoparasitism were significantly higher at Columbretes (Kruskall-Wallis $\chi_{2}^{2}=8.34, \mathrm{p}=0.015$; $\chi_{2}^{2}=6.23, p=0.044$ respectively). However, chickfeeding kleptoparasitism was not significantly different between colonies $\left(\chi_{2}^{2}=1.29, \mathrm{p}=0.525\right)$, although rates were very low in all three colonies (Table 1). Neither egg predation nor chick predation were significantly different between colonies $\left(\chi_{2}^{2}=\right.$ 5.06, $\mathrm{p}=0.080$ and $\chi_{2}^{2}=1.65, \mathrm{p}=0.439$ respectively). Percentages of success are shown in Table 2. Success was always lower than 50\%, except for chick-feeding kleptoparasitism, which is probably an artifact due to low sampling $\left(\mathrm{N}_{\mathrm{i}}=5\right)$. The highest success rate was recorded for aerial kleptoparasitism $(47.6 \%)$ and the lowest for courtship-feeding klep-

TABLE 2. - Percentages of success for the different interactions between the two species. $\mathrm{Ni}=$ number of interactions observed (results are pooled for the three colonies).

\begin{tabular}{lrc}
\hline & $\mathrm{Ni}$ & $\%$ success \\
\hline Aerial kleptoparasitism & 21 & 47.6 \\
Courtship-feeding kleptoparasitism & 13 & 7.7 \\
Chick-feeding kleptoparasitism & 5 & 80.0 \\
Egg predation & 13 & 30.8 \\
Chick predation & 34 & 41.2 \\
\hline
\end{tabular}


TABLE 3. - Response rates (in mean number per hour and its standard deviation SD) to disturbances depending on whether nests observed were at the edge or at the centre of the subcolony. Results are pooled for the Chafarinas and Ebro Delta colonies (see Methods for explanation). $\mathrm{N}=$ Number of days observed (only days with a minimum of $10 \mathrm{~h}$ of observation were considered).

\begin{tabular}{|c|c|c|c|c|c|c|}
\hline & \multicolumn{2}{|c|}{ Alarm calls } & \multicolumn{2}{|c|}{$\begin{array}{l}\text { Agonistic response } \\
\text { to aerial disturbances }\end{array}$} & \multicolumn{2}{|c|}{$\begin{array}{l}\text { Agonistic response } \\
\text { to terrestrial disturbances }\end{array}$} \\
\hline & Edge & Centre & Edge & Centre & Edge & Centre \\
\hline $\begin{array}{l}\mathrm{N} \\
\text { mean } \\
\mathrm{SD}\end{array}$ & $\begin{array}{c}5 \\
0.18 \\
0.18\end{array}$ & $\begin{array}{c}6 \\
0.26 \\
0.34\end{array}$ & $\begin{array}{c}5 \\
0.38 \\
0.16\end{array}$ & $\begin{array}{c}6 \\
0.005 \\
0.005\end{array}$ & $\begin{array}{c}5 \\
0.64 \\
0.29\end{array}$ & $\begin{array}{c}6 \\
0.19 \\
0.11\end{array}$ \\
\hline $\begin{array}{l}\mathrm{U} \\
\mathrm{P}\end{array}$ & \multicolumn{2}{|c|}{166.0} & \multicolumn{2}{|c|}{126.0} & \multicolumn{2}{|c|}{109.0} \\
\hline
\end{tabular}

TABLE 4. - Response rates (in mean number per hour and its standard deviation SD) to disturbances depending on the colony. $\mathrm{N}=$ Number of days observed (only days with a minimum of $10 \mathrm{~h}$ of observations were considered). A single-factor non-parametric analysis of variance by ranks (K-W test) is shown.

\begin{tabular}{|c|c|c|c|c|c|c|c|c|c|}
\hline & \multicolumn{3}{|c|}{ Alarm calls } & \multicolumn{3}{|c|}{$\begin{array}{l}\text { Agonistic response } \\
\text { to aerial disturbance }\end{array}$} & \multicolumn{3}{|c|}{$\begin{array}{c}\text { Agonistic response } \\
\text { to terrestrial disturbance }\end{array}$} \\
\hline & Delta & Chafarinas & Columbretes & Delta & Chafarinas & Columbretes & Delta & Chafarinas & Columbretes \\
\hline $\mathrm{N}$ & 19 & 8 & 4 & 19 & 8 & 4 & 19 & 8 & 4 \\
\hline Mean & 1.26 & 5.12 & 5.69 & 0.00 & 1.12 & 1.87 & 0.42 & 5.37 & 6.24 \\
\hline SD & 1.91 & 3.56 & 5.41 & 0.00 & 1.55 & 2.01 & 1.01 & 3.92 & 4.08 \\
\hline${\underset{\mathrm{P}}{2}}_{2}^{2}$ & & $\begin{array}{c}4.61 \\
0.10\end{array}$ & & & $\begin{array}{c}6.58 \\
<0.05\end{array}$ & & & $\begin{array}{l}14.21 \\
<0.001\end{array}$ & \\
\hline
\end{tabular}

toparasitism (7.7\%). Grouping kleptoparasitic interactions and predation, the success rate was almost the same (38\%, no statistical difference: $\chi^{2}{ }_{1}=0.00$, $\mathrm{p}=0.998$ ). Table 3 shows the response rates to disturbance depending on whether the group of nests observed was in the centre or at the edges of a subcolony. Aggressive response rates to both aerial and terrestrial intrusions were significantly higher at the boundaries than at the centre of the sub-colonies, whereas no significant differences were detected in alarm calls between centre and periphery. Table 4 compares the response rates of Audouin's gulls to disturbance in the three colonies. The aerial and terrestrial agonistic response rates were significantly different among locations, with higher response rates at Columbretes and Chafarinas Islands than at the Ebro Delta. Differences in alarm calls among colonies were not statistically significant.

\section{DISCUSSION}

Rates of kleptoparasitism and predation recorded at the Ebro Delta, Chafarinas and Columbretes Islands may be considered low when compared with those recorded in similar studies dealing with other
Larus species (Fuchs, 1977; Smith, 1991; Velarde, 1992; Hario, 1994). The results suggest that interactions did not represent a threat (at least as decrease of breeding success) in any of the three colonies. Only ca. $10 \%$ of chicks hatched at the three colonies were preyed upon by yellow-legged gulls, and most of them were chicks that had moved away from their nests (and thus from their parents), chicks with bad body condition which had been abandoned by their parents, or recently-dead chicks (own obs.). Rates of kleptoparasitism and predation were also lower than those found for other seabird species (great skua Stercorarius skua and Arctic skuas S. parasiticus kleptoparasitising and predating on kittiwakes Rissa tridactyla, gannets Morus bassanus or puffins Fratercula arctica), where kleptoparasitism and predation resulted in a decrease in breeding success (Anderson 1976). Oro et al. (1996) suggested that the number of interactions between the two species could be influenced by the ratio of the numbers of both species present at the colony during breeding. At the Chafarinas Islands, the population of the yellow-legged gull decreased during the period 19851994 from 5,000 to 1,500 breeding pairs, due to the culling of both eggs and adults, carried out from 1987 to 1993. At the same time, the population of 
Audouin's gull increased from 2,000 to ca. 4,000 breeding pairs. Thus, the ratio between the yellowlegged gull and Audouin's gull changed from 1:3 to 3:1 in less than ten years. This exclusion experiment clearly shows the existence of competition between the two gull species. Thus, the situation during the present study was probably better for Audouin's Gull than that reported by Bradley (1986) in the same colony (see also Bradley and Monaghan, 1986). Our results also suggest that the rate of interactions were highest at Columbretes Islands and lowest at the Ebro Delta, where the yellow-legged gull to Audouin's gull ratio showed the two extreme values (1.6 and 0.16 respectively) (see also Oro, 1996a). Another factor that probably influenced the rate of interactions was food availability. As indicated by González-Solis et al. (1997), interactions between the two species at Chafarinas peak off when yellowlegged gulls are food-stressed over a period of days without sardine fishery activity. In addition chick predation was significantly higher only during the period when yellow-legged gulls have fledglings. At the Ebro Delta, the effects of low food availability brought about by a trawling fishing moratorium also caused a marked increase in predation by yellowlegged gulls of chicks and even adults of Audouin's gull (Oro and Martínez-Vilalta, 1994). Such an increase also coincided with hatching and early growth stages of yellow-legged gull chicks (op. cit.). During this period of moratorium Audouin's gulls were recorded kleptoparasitising terns (Oro, 1996b). Regehr and Montevecchi (1997) also recorded increased predation of Kittiwake eggs by Larus gulls under an extreme food-stress situation. Similarly, Philips et al. (1997) found that breeding great skuas Catharacta skua fed extensively upon other seabirds only at colonies where there was a lack of traditional feeding sources (fish or fisheries discards). Food availability was also different between the study colonies, being higher at the Ebro Delta than at the Columbretes or the Chafarinas islands (Oro et al., 1996; Ruiz et al., 1998; Pedrocchi et al., 2002). Even when the trawling moratoria were established around the Ebro Delta and Columbretes colonies during the study (in 1994 at the Ebro Delta and in 1997 at Columbretes), foraging resources were much higher at the former than at the latter (Oro et al., 1996). However, even though interaction rates seemed different among colonies, it is still unknown how representative of the whole colony results from a subsample of large colonies are (as was the case for the Ebro Delta and Chafarinas colonies).
Although Castilla (1995) found no significant interaction between predation of Audouin's dummy eggs and location within the colony, we found an effect of breeding at the periphery. Lack of vegetation cover probably explains the increase in response rate at the edges of the colonies, since it was more difficult for predators to land in the central areas of the sub-colonies (e.g. Becker, 1995; own observations). The different degree of response of Audouin's gull to yellow-legged gulls was probably the result of the variation in interference rates with colony site. Gulls reacted more intensely at the Columbretes colony, probably because this was by far the smallest colony and individuals were forced to participate in any intrusions or attacks by yellowlegged gulls.

Kleptoparasitism and predation of yellow-legged gulls on Audouin's gulls took place during daylight hours or full moon nights (authors, unpublished data), which is coincident with the behaviour observed for herring gulls Larus argentatus (Nocera and Kress, 1996). Since Audouin's gulls show nocturnal feeding activity, they could feed their chicks at night and hence avoid disturbances by yellowlegged gulls (see Nelson, 1989 for an example dealing with nocturnal predation in Laridae).

Success rates were similar to those recorded by several authors for other gull species or for other colonies (Verbeek, 1977; Furness, 1987; Amat and Aguilera, 1990; Velarde, 1992; Bosch, 1996). The occurrence of interactions and their success probably depends on the degree of specialisation of the predator or kleptoparasite (Negro et al., 1992; Spear, 1993; Gilardi, 1994; Hario, 1994; Finney et al., 2001). Indeed, at Chafarinas, a pair of yellow-legged gulls was observed preying repeatedly on Audouin's gull chicks, with a success of $70 \%$. In addition, a few individuals of the yellow-legged gull, identifiable by their plumage, were involved in most of the attacks recorded at the Ebro Delta. Additional factors like duration of attack and group size also seem to be relevant (see Hatch, 1970; Oro and MarínezVilalta, 1994).

The impact of yellow-legged gulls through predation or kleptoparasitism on Audouin's gulls during our study is neither clear nor proved. Even though yellow-legged gulls were continuously patrolling colonies of Audouin's gulls and interactions actually occurred, the consequences for Audouin's gulls do not seem to be important. Hatch and Hatch (1990) considered that although avian predators were the dominant proximate cause of 
egg-chick losses in a colony of eight seabird species in the western Gulf of Alaska, food supply was ultimately responsible for variation in all the major components of productivity. Consequently, any culling or limiting actions on yellow-legged gulls could not be justified just by these impacts. However, evaluations of the effects of these programmes are scarce (see Bosch et al., 2000; Finney et al., 2001). More studies are needed to assess these interactions and others such as competition for space with yellow-legged gulls (e.g. Sadoul et al., 1996), which could represent a threat to less aggressive species such as Audouin's gulls (see Hatch, 1970; Oro et al., 1996; Sadoul et al., 1996).

\section{REFERENCES}

Amat, J.A. and E. Aguilera. - 1990. Tactics of black-headed gulls robbing egret and waders. Anim. Behav., 39: 70-77.

Anderson, M. - 1976. Predation and kleptoparasitism by skuas in a Shetland seabird colony. Ibis, 118: 208-217.

Becker, P.H. - 1995. Effects of coloniality on gull predation on common tern (Sterna hirundo) chicks. Colonial Waterbirds, 18: 11-22.

Bosch, M. -1996 . The effect of culling on attacks by yellow-legged gulls (Larus cachinnans) upon three species of herons. Waterbirds, 19: 248-252.

Bosch, M., D. Oro, F.J. Cantos and M. Zabala. - 2000. Short-term effects of culling on the ecology and population dynamics of the yellow-legged gull. J. Appl. Ecol., 37: 369-385.

Bradley, P. - 1986. The breeding biology of Audouin's Gull on the Chafarinas islands. NATO ASI Series. Vol G12. Mediterranean Marine Avifaune. Ed. Medmaravis and X. Monbailliu. Berlin.

Bradley, P. and P. Monaghan. - 1986. Audouin's Gull and the Chafarinas Islands Game Reserve. Oryx, 20: 161-164.

Brockmann, H.J. and C.J. Barnard. - 1979. Kleptoparasitism in birds. Anim. Behav., 27: 487-514.

Burger, J. and M. Gochfeld. - 1988. Defensive aggression in terns: effect of species, density and isolation. Aggres. Behav., 14: 169-178.

Burger, J. and M. Gochfeld. - 1992. Experimental evidence for aggressive antipredator behaviour in black skimmers (Rynchops niger). Aggres. Behav., 18: 241-248.

Castilla, A.M. - 1995. Intensive predation of artificial Audouin's Gull nests by the Yellow-legged Gull in the Columbretes Islands, Spain. Colonial Waterbirds, 18: 226-230.

Cavanagh, P.M. and C.R. Griffin. - 1993. Responses of nesting common terns and laughing gulls to flyovers by large gulls. Wil. Bull., 105: 333-338.

Finney, S.K., S. Wanless, M.P. Harris and P. Monaghan. - 2001. The impact of gulls on puffin reproductive performance: an experimental test of two management strategies. Biol. Cons., 98: $159-165$

Fuchs, E. - 1977. Kleptoparasitism of Sandwich Terns Sterna sandvicensis by Black-headed Gulls Larus ridibundus. Ibis, 119: 183-190.

Furness, R.W. - 1987. Kleptoparasitism in seabirds. In: SEABIRDS, Ed. J.P.Croxall. Cambridge University Press.

Gilardi, J.D. - 1994. Great Frigatebird Kleptoparasitism: Sex-Specific Host Choice and Age-Related proficiency. Condor, 96: 987-993.

González-Solis, J., X. Ruiz and L. Jover. - 1997. Influence of food availability on interactions between Larus cachinnans and L. audouinii. Can. J. Zool., 75: 719-724.

Hario, M. - 1994. Reproductive performance of the nominate lesser black-backed gull under the pressure of herring gulls predation. Ornis Fennica, 71: 1-10.

Hatch, J.J. - 1970. Predation and piracy by gulls at a ternery in Maine. Auk, 87: 244-254.

Hatch, J.J. - 1975. Piracy by Laughing Gulls Larus atricilla: an example of the selfish group. Ibis, 117: 357-365.

Hatch, S.A. and M.A. Hatch. - 1990. Components of breeding productivity in a marine bird community: key factors and concordance. Can. J. Zool., 68: 1680-1690.

Le Corre, M. and P. Jouventin. - 1997. Kleptoparasitism in tropical seabirds: vulnerability and avoidance responses of a host species, the red-footed booby. Condor, 99: 162-168.

Negro, J.J., J.A. Donázar and F. Hiraldo. - 1992. Kleptoparasitism and cannibalism in a colony of Lesser Kestrels (Falco naumanni). J. Rap. Res., 26: 225-228.

Nelson, D.A. - 1989. Gull Predation on Cassin's Auklet Varies with the Lunar Cycle. Auk, 106: 495-497.

Nocera, J.J. and S.W. Kress. - 1996. Nocturnal predation on Common Terns by Great Black-backed gulls. Colonial Waterbirds, 19: $277-279$.

Oro, D. and A. Martínez-Vilalta. - 1994. Factors affecting kleptoparasitism and predation rates upon a colony of Audouin's Gull (Larus audouinii) by Yellow-legged Gulls (Larus cachinnans) in Spain. Colonial Waterbirds, 17: 35-41.

Oro, D. - 1996a. Colonial seabird nesting in dense and small subcolonies: an advantage against aerial predation. Condor, 98: 848-850.

Oro, D. - 1996b. Interspecific kleptoparasitism inAudouin's Gull Larus audouinii at the Ebro Delta, northeast Spain: a behavioural response to low food availability. Ibis, 138: 218-221.

Oro, D., X. Genovart, X. Ruiz, J. Jiménez and J. García-Gans. 1996. Differences in diet, population size and reproductive performance between two colonies of Audouin's gull Larus audouinii affected by a trawling moratorium. J. Avian Biol., 27: 245-251.

Pedrocchi, V., D. Oro, J. González-Solís, X. Ruiz and L. Jover. 2002. Differences in feeding ecology between the two largest breeding colonies of Audouin's gulls: the effects of fishery activities. Sci. Mar., 66: 313-320.

Philips, R.A., P. Catry, D.R. Thompson, K.C. Hamer and R.W. Furness. - 1997. Inter-colony variation in diet and reproductive performance of great skuas Catharacta skua. Mar. Ecol. Progr. Ser., 152: 285-293.

Regehr, H.M. and W.A. Montevecchi. - 1997. Interactive effects of food shortage and predation on breeding failure of black-legged kittiwakes: indirect effects of fisheries activities and implications for indicator species. Mar. Ecol. Progr. Ser., 155: 249-260.

Ricklefs, R.E. and G.L. Miller. - 2000. Ecology. Fourth Edition. W.H. Freeman and Company. New York.

Ruiz, X., J. González-Solis, D. Oro and L. Jover. - 1998. Body size variation in Audouin's gulls Larus audouinii: a density-dependent effect? Ibis, 140: 431-438.

Sadoul, N., A.R. Johnson, J.G. Walmsley and R. Levêque. - 1996. Changes in the numbers and the distribution of colonial charadriformes breeding in the Camargue, southern France. Colonial Waterbirds, 19: 46-58.

Shealer, D.A. and J. Burger. - 1992. Differential responses of Tropical Roseate Terns to aerial intruders throughout the nesting cycle. Condor, 94: 712-719.

Smith, G.C. - 1991. Kleptoparasitic Silver Gulls Larus novaehollandiae on the northern great barrier reef Queensland. Corella, 15: 41-44.

Spear, L.B. - 1993. Dynamics and effects of western gulls feeding in a colony of guillemots and Brandt cormorants. J. Anim. Ecol., 62: 399-414.

Velarde, E. - 1992. Predation of Heermann's Gull (Larus heermanni) chicks by Yellow-footed Gulls (Larus livens) in dense and scattered nesting sites. Colonial Waterbirds, 15: 8-13.

Verbeek, N.A.M. - 1977. Interactions between herring and lesser blacked gulls feeding on refuse. Auk, 94: 726-735. 